\title{
UDC 621.395 \\ EVALUATION OF VOICE TRANSMISSION QUALITY IN THE LTE NETWORKS
}

\author{
Ivan P. Vetoshko, Vyacheslav I. Noskov \\ Institute of Telecommunication Systems \\ Igor Sikorsky Kyiv Polytechnic Institute, Kyiv, Ukraine
}

\begin{abstract}
Background. LTE mobile networks combine packet network technology and radio technology. Parameters of packet and radio subsystems significantly affects the quality of all traffic types transmission, especially telephone traffic, as the most demanding to such parameters of network transmission as delay, jitter and packet loss rate. The recommendations of the International Telecommunication Union and the documents of the partner organization of telecommunications operators (3GPP) contain hypothetical reference models, targets for end-to-end connection quality, and lists the factors that affect the quality (QoS) of VoLTE services. In addition, the network points are shown where you need to measure the quality of telephone traffic and tools for quality assessment. The quality of telephony services is assessed according to the E-model using the method of determining the mean opinion score (MOS). However, this technique is intended primarily to determine the MOS during the network planning. To calculate the MOS in a working network, you have to measure such network performance first such as voice delay and packet loss rate. This article presents the method of calculating MOS in the LTE network based on the E-model and presents the results of practical quality studies.
\end{abstract}

Objective. The purpose of this article is research the impact of delay and packet loss ratio and voice codec characteristics in the real LTE network on quality of telephone services.

Methods. Analysis of factors affecting on telephone services quality and analysis MOS assessment methods. Practical studies of the delay and packet loss ratio affect the MOS level in various conditions of radio coverage and network load.

Results. Practical results of delay and packet loss ratio influence on the telephone services quality in the LTE network. Calculated MOS based on the practically measured delay and packet loss ratio.

Conclusions. The combination of packet technologies, modern AMR-WB codecs and QoS support mechanisms in the LTE networks provides high quality perception of voice messages at the level of not less than 4 on the MOS scale. With a delay not exceeding $180 \mathrm{~ms}$, a sufficiently high quality of voice transmission is ensured $(\mathrm{MOS} \approx 4)$. VoLTE technology using the AMR-WB codec is quite resistant to packet loss and provides high quality perception of voice messages at a packet loss ratio of up to $1 \%$.

Keywords: LTE; MOS; QoS; VoLTE; delay; jitter; packet loss ratio.

LTE mobile networks use packet transmission methods to provide a wide range of info-communication services. Although in modern networks data traffic is dominated, the popularity of telephone services are not declining because they are most consistent with the natural forms of human communication. The basis of the telephone service is the transfer of voice from one user to another. In LTE networks, voice transmission is provided by VoLTE technology, which involves the use of adaptive multi-speed codecs and packet format transmission in the network. The assessment of the voice transmission quality based on the E-model in accordance with the recommendations of the ITU-T. It is defined as the average value of subjective assessments of users [1]. This score is called Mean Opinion Score (MOS) and has a value of 1, 2, 3, 4, 5. MOS, depends on the voice codec and network performances, such as delay, jitter and packet loss rate. Due to the greater capacity of the radio subsystem, LTE networks mainly use Wide Band
(WB) codecs, which provide voice transmission in the band from 50 to $7000 \mathrm{~Hz}$. This has a positive impact on speech perception quality by subscribers and, accordingly, increases the MOS. AMR-WB voice codec is widely used in LTE networks. This codec is described in the ITU-T Recommendation G.722.2 [4]. The method for calculating the MOS based on the E-model and mainly used at the network planning stage. For the LTE mobile network, it is interesting to study MOS in the network operation process as dependence on the radio coverage quality and under the conditions of the greatest voice traffic load. This article presents the results of such studies.

Recommendation ITU-T G.107.1 [2] provides a method for determining the MOS in the case of using the WB-codec through a preliminary calculation of the rating factor $(\mathrm{R})$ :

$$
R=R o-I s-I d-I e, e f f+A,
$$


where: $R o=129$ - a factor that is determined by the signal to noise ratio in assuming that noise is generated by not only the communication channel, but also other sources in the user's room; Is - a factor due to the sum of various negative influences during voice transmission. Is-factor is not currently studied for the WB-codec well. So it is considered to equal it to zero [2]; Id - the factor which reflect the negative impact of the delay on voice quality due to a set of reasons; Ie, eff negative impact factor due to the properties of the codec and the packet loss factor; $A$ is the "advantage" factor, which is not due to the quality of the codec or channel, but rather the user's expectations about the quality of service in certain conditions. The effect of this factor has not been studied yet for the WB-codec, so it is considered to equal it to zero [2].

The negative impact factor of the delay consists of three components:

$$
I d=I d t e+I d l e+I d d
$$

where: Idte - a factor caused by the echo due to the delay on the side of the speaker; Idle - a factor caused by the echo due to the delay on the part of the listener; Idd - a factor caused by the echo, which cannot be compensated by echo-canceler due to much delay.

The main factor in the negative delay impact on the quality of voice communication is the echo on the speaker's side, which is calculated by the formulas [2]:

$$
\begin{gathered}
\text { Idte }=\left[\frac{94,769-R e}{2}+\sqrt{\left.\frac{(94,769+R e)^{2}}{4}+100\right] \times}\right. \\
\mathrm{x}\left(1-e^{-T s}\right) ; \\
R e=80+2,5(T E R V-14) ; \\
T E R V=T E L R-40 * \log \frac{1+\frac{T s}{10}}{1+\frac{T s}{150}}+6 * e^{-0,3 T s^{2}}
\end{gathered}
$$

In the above formulas, TELR determines the volume level of the echo, and Ts - the end-toend delay of voice data.

The influence of voice codec parameters and the packet loss rate can be estimated by the following formula [2]:

$$
I e, e f f=I e+(95-I e) \frac{P p l}{P p l+B p l},
$$

where: $I e$ is the factor of the voice codec parameters influencing on the voice quality, which depends on the type of codec and its speed. For AMR codec [4] which mainly used in LTE networks, the impact factor Ie can be considered to equal it to 8 [3] in case of using $23.85 \mathrm{kbit} / \mathrm{c}$ transmission rate; $P p l$ - packet loss ratio in percentages; $\mathrm{Bpl}$ is the coefficient of the codec resistance to packet loss. Codec resistance to packet losses for WB AMR codec is too high and due to ITU-T recommendations [2] can be considered to equal it to 7.3 .

The following relations are used to calculate the MOS [2]:

$$
R x=\frac{R}{1,29}
$$

If $R x<0$, then $\mathrm{MOS}=1$;

If $0<\mathrm{Rx}<100$, then

$\operatorname{MOS}=1+0,035 R x+R x(R x-60) *$

$*(100-R x) * 7 * 10^{-6}$;

If $\mathrm{Rx}>1$, then $\mathrm{MOS}=4,5$.

To calculate the MOS, it is also possible to use the graph in Fig. 1 which built on formulas (5).

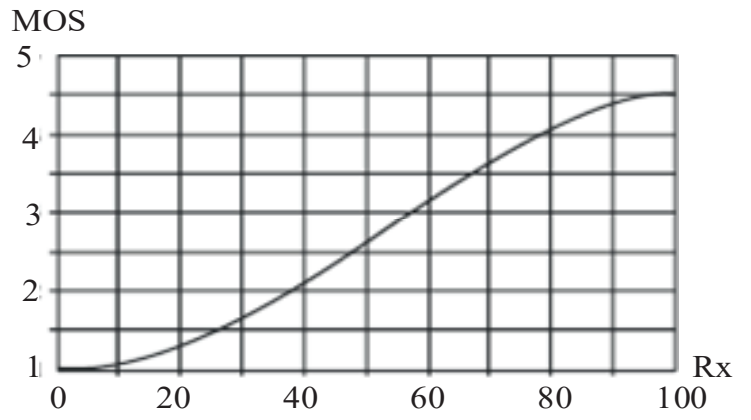

Fig. 1. Defining the MOS

To determine the MOS according to above formulas in a real LTE network, was performed a test on the network fragment. The goal of this test is to obtain the initial data for packet delay and packet losses under poor and good radio coverage conditions. The VoLTE tested network included more than 4000 subscribers, which randomly distributed between different base stations. Test has been performed at the hour of maximum traffic load. Traffic load for some base station reached the amount when blocking probability was up to $2 \%$. Poor radio coverage conditions were considered when the input signal level for user terminal was in the range from $-95 \mathrm{dBm}$ to $110 \mathrm{dBm}$. The coverage good was considered if signal level was in the range from $-70 \mathrm{dBm}$ to -80 $\mathrm{dBm}$. 
VoLTE phone calls were made both when the user was stationary and when moving at a speed of 30 to $70 \mathrm{~km} / \mathrm{h}$.

The WB AMR voice codec was used at a maximum speed of $23.85 \mathrm{kbps}$. The measurement period was $10 \mathrm{~s}$. NetNumen ZTE NMS tools was used to measure delay and jitter.

The values of the packet loss factor and the jitter in poor coverage conditions were differ during the measurement even at the same signal levels. It can be explained by additional variable voice traffic load impact. The packet loss ratio was in the range of $0.1 \ldots 1.8 \%$, and the delay jitter varied within $2 \ldots 17.1 \mathrm{~ms}$. The delay, which was measured in conditions of good coverage, was $140 \ldots 185 \mathrm{~ms}$ and depended on the load of the base station with voice traffic.

Based on the measurements result and using the method described above, the expected MOS values are calculated for conditions of good coverage, where the factor of influence mainly is delay, and for conditions of poor coverage, where the quality of received voice perception is simultaneously affected by delay and packet losses. Graphs with the results of MOS calculations are presented in Fig. 2 and 3.

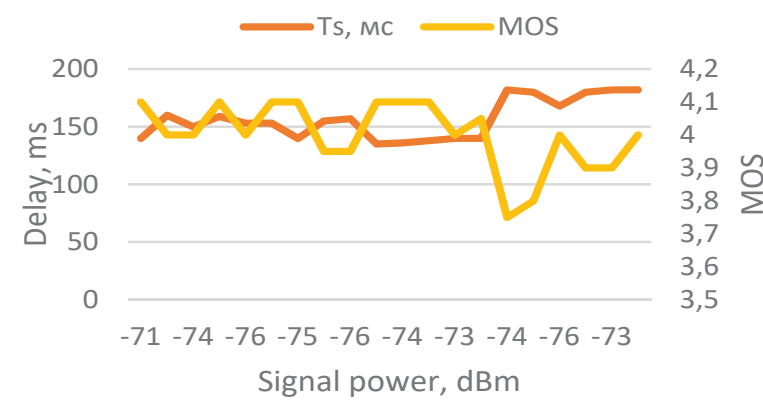

Fig. 2. Dependence of delay and MOS on the signal level under good radio coverage conditions

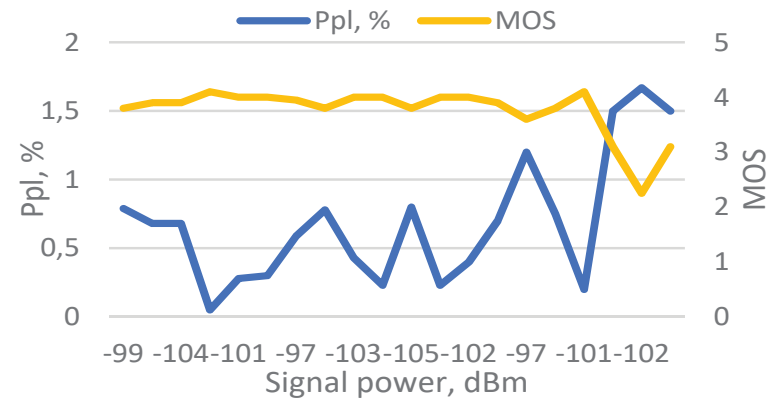

Fig. 3. Dependence of packet loss factor (Ppl) and MOS on the signal level in poor radio coverage conditions.
Graphs in Fig. 2 show that if the delay does not exceed $180 \mathrm{~ms}$ under good radio coverage conditions, the quality of voice message perception is at a good level (MOS $\approx 4)$. The average value of the delay during testing was $157.7 \mathrm{~ms}$. Thus, under good radio coverage, VoLTE technology with AMR-WB codec shows high quality voice transmission in the band up to 7 $\mathrm{kHz}$.

Graphs in Fig. 3 show that if the packet loss ratio does not exceed $1 \%$, the quality of perception of voice messages also remains quite high $(\mathrm{MOS} \approx 4)$, despite the poor quality of radio coverage. When the PLR increases above 1.0\%, the corresponding MOS values decrease sharply to lower values $(2.5 \ldots 3)$, which means a poor perception of voice messages.

One of the ways to further improving the quality of voice services is the introduction of SWB (Super Wide Band - 50.. $14000 \mathrm{~Hz}$ ) and FB (Full Band - 50.. 20,000 Hz) codecs. One of these codecs is the EVS codec (Enhanced Voice Service). Like the AMR codec, it can adaptively change the baud rate, but in larger range (5.9 to $128 \mathrm{kbps})$. It has the following main advantages: voice / sound activity detector, baud rate adaptation, error masking mechanism, comfortable noise generation, advanced buffer management for jitter compensation and channel status notification mode. Under the same conditions as for the AMR-WB codec, the EVS codec potentially increases the MOS score by almost 0.5 points. However, further practical studies of the behaviour of these codecs in the LTE network are needed.

\section{Conclusions}

1. The combination of packet technologies, modern AMR-WB codecs and QoS support mechanisms in the LTE networks provides high quality perception of voice messages at the level of not less than 4 on the MOS scale.

2. With a delay not exceeding $180 \mathrm{~ms}$, a sufficiently high quality of voice transmission is ensured (MOS $\approx 4$ ).

3. VoLTE technology using the AMR-WB codec is quite resistant to packet loss and provides high quality perception of voice messages at a packet loss ratio of up to $1 \%$.

\section{References}

1. ITU-T Recommendation G.107 (06/2015) The E-model: a computational model for use in transmission planning. 
2. ITU-T Recommendation G.107.1 (06/2019) International telephone connections and circuits. Transmission planning and the E-model. Wideband E-model.

ITU-T Recommendation G.113 (11/2007) International telephone connections and circuits. General Recommendations on the transmission quality for an entire international telephone connection. Transmission impairments due to speech processing.

3. ITU-T Recommendation G.722.2 (07/2003) Wideband coding of speech at around $16 \mathrm{kbit} / \mathrm{s}$ using Adaptive Multi-Rate Wideband (AMRWB).

\section{Ветошко І.П., Носков В.I.}

Оцінка якості передачі голосу в мережах LTE

Проблематика. Мережі мобільного зв'язку LTE поєднують в собі технології пакетних мереж та радіотехнології. Комплекс параметрів функціювання пакетної та радіо підсистем суттєво впливають на якість передачі всіх видів трафіку, особливо телефонного трафіку, як найбільш вимогливого до таких параметрів передачі в мережі як затримка, джитер затримки та коефіцієнт втрат пакетів. В рекомендаціях Міжнародного Союзу Електрозв'язку та в документах партнерської організації телекомунікаційних операторів 3GPP наведені гіпотетичні еталонні моделі, цільові показники якості наскрізного з'єднання, та перераховані фактори, що впливають на якість (QoS) надання послуг за технологією VoLTE. Також показані точки мережі, в яких потрібно вимірювати якість передачі телефонного трафіку та інструментарій і моделі для оцінки якості. Якість надання послуг телефонії оцінюється відповідно до Е-моделі за методикою визначення середньої експертної оцінки (MOS). Однак, ця методика призначена насамперед для визначення MOS при плануванні мережі. Для розрахунку MOS у вже працюючій мережі потрібно спочатку провести вимірювання таких показників роботи мережі, як затримка голосового повідомлення із кінця в кінець та коефіцієнт втрат пакетів. В даній статті представлена методика розрахунку MOS в мережі LTE за Е-моделлю та наведені результати практичних досліджень якості передачі голосових повідомлень.

Мета досліджень. Оцінка впливу затримки та коефіцієнту втрати пакетів в реальній мережі LTE та характеристик кодеку на якість надання телефонних послуг.

Методика реалізації. Аналіз факторів, що впливають на якість надання телефонних послуг, методики MOS, інструментарію оцінки якості. Практичні дослідження впливу затримки та коефіцієнту втрат пакетів в мережі LTE на рівень MOS в різних умовах радіопокриття та навантаження мережі.

Результати досліджень. Практичні результати впливу затримки та коефіцієнту втрат пакетів на якість надання телефонних послуг в мережі LTE. Розрахункові дані MOS на основі практичних вимірів затримки та коефіцієнту втрат пакетів..

Висновки. Поєднання в мережах LTE пакетних технологій, сучасних кодеків AMR-WB та механізмів підтримки QoS забезпечує високу якість сприйняття голосових повідомлень на рівні не нижче 4 за шкалою MOS. При затримці, що не перевищує 180 мс, забезпечується достатньо висока якість передачі голосу (MOS $\approx$ 4). Технологія VoLTE з використанням кодеку AMR-WB достатньо стійка до втрат пакетів і забезпечує високу якість сприйняття голосових повідомлень при коефіцієнту втрат пакетів до $1 \%$.

Ключові слова: LTE; MOS; QoS; VoLTE; затримка; джитер затримки; коефіцієнт втрат пакетів.

Ветошко И.П., Носков В.И.

Оценка качества передачи голоса в сетях LTE

Проблематика. Сети мобильной связи LTE совмещают в себе технологии пакетных сетей и радиотехнологии. Комплекс параметров функционирования пакетной и радиоподсистем оказывает существенное влияние на качество передачи всех видов трафика, особенно телефонного трафика, как наиболее требовательного к таким параметрам передачи в сети как задержка, джитер задержки и коэффициент потерь пакетов. В рекомендациях Международного Союза Электросвязи и в документах партнерской организации телекоммуникационных операторов 3GPP приведены гипотетические эталонные модели, целевые показатели качества сквозного соединения и перечисленные факторы, влияющие на качество (QoS) предоставления услуг по технологии VoLTE. Также показаны точки сети, в которых необходимо измерять качество передачи телефонного трафика и инструментарий и модели для оценки свойства. Качество услуг телефонии оценивается в соответствии с Е-моделью по методике определения средней экспертной оценки (MOS). Однако эта методика предназначена прежде всего для определения MOS при планировании сети. Для расчета MOS в уже работающей сети нужно сначала произвести измерение таких показателей работы сети, как задержка голосового сообщения из конца в конец и коэффициент потерь пакетов. В данной статье представлена методика расчета MOS в сети LTE по Е-модели и приведены результаты практических исследований качества передачи голосовых сообщений. 
Цель исследований. Оценка влияния задержки и коэффициента потерь пакетов в реальной сети LTE и характеристик кодека на качество телефонных услуг.

Методика реализации. Анализ факторов, влияющих на качество предоставления телефонных услуг, методики оценки MOS, инструментария оценки качества. Практические исследования влияния задержки и коэффициента потерь пакетов в сети LTE на уровень MOS в различных условиях радиопокрытия и нагрузки сети.

Результаты исследований. Практические результаты оценки влияния задержки и коэффициента потерь пакетов на качество телефонных услуг в сети LTE. Расчетные данные MOS на основе практических измерений задержки и коэффициента потерь пакетов.

Выводы. Сочетание в сетях LTE пакетных технологий, современных кодеков AMR-WB и механизмов поддержки QoS обеспечивает высокое качество восприятия голосовых сообщений не ниже чем 4 по шкале MOS. При задержке не превышающей 180 мс обеспечивается достаточно высокое качество передачи голоса $(\mathrm{MOS} \approx 4)$. Технология VoLTE с использованием кодека AMR-WB достаточно устойчива к потерям пакетов и обеспечивает высокое качество восприятия голосовых сообщений при коэффициенте потерь пакетов до $1 \%$.

Ключевые слова: LTE; MOS; QoS; VoLTE; задержка; джитер задержки; коэффициент потерь пакетов. 